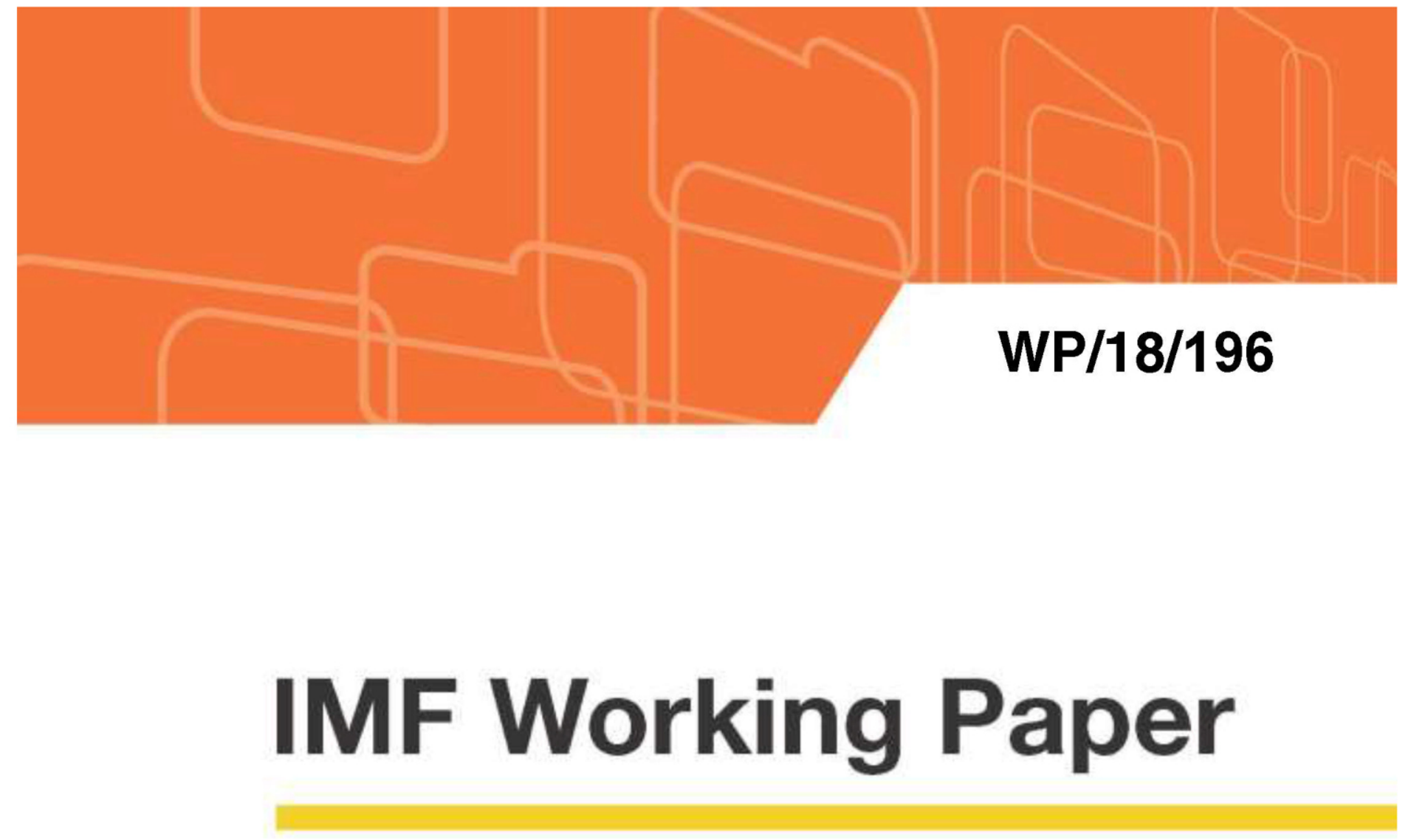

\title{
Household Wealth and Resilience to Financial Shocks in Italy
}

by Daniel Garcia-Macia

IMF Working Papers describe research in progress by the author(s) and are published to elicit comments and to encourage debate. The views expressed in IMF Working Papers are those of the author(s) and do not necessarily represent the views of the IMF, its Executive Board, or IMF management. 


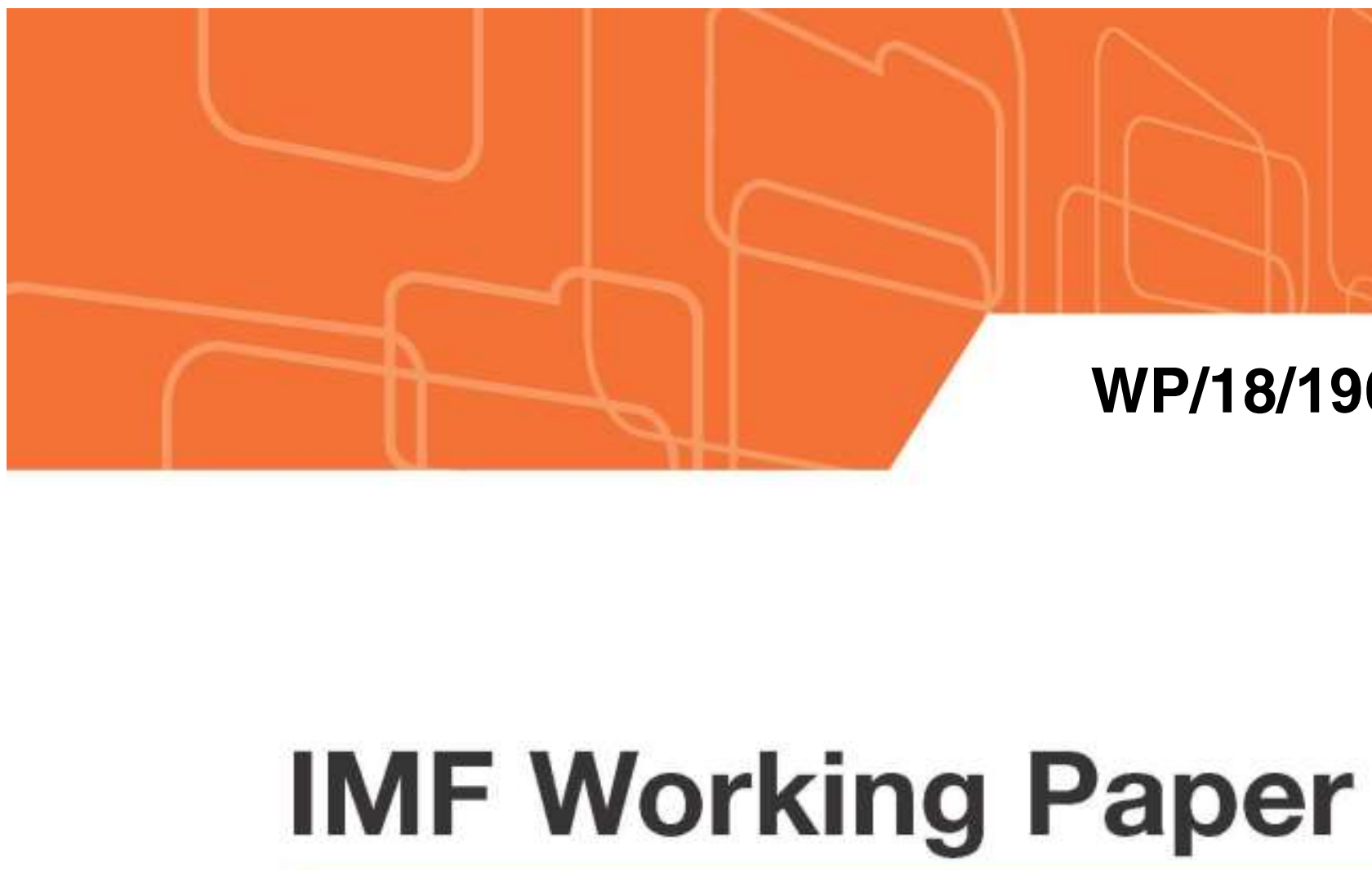

\section{Household Wealth and Resilience to Financial Shocks in Italy}

by Daniel Garcia-Macia

IMF Working Papers describe research in progress by the author(s) and are published to elicit comments and to encourage debate. The views expressed in IMF Working Papers are those of the author(s) and do not necessarily represent the views of the IMF, its Executive Board, or IMF management. 


\title{
IMF Working Paper
}

European Department

\section{Household Wealth and Resilience to Financial Shocks in Italy ${ }^{1}$ \\ Prepared by Daniel Garcia-Macia}

Authorized for distribution by Rishi Goyal

August 2018

\section{IMF Working Papers describe research in progress by the author(s) and are published to elicit comments and to encourage debate. The views expressed in IMF Working Papers are those of the author(s) and do not necessarily represent the views of the IMF, its Executive Board, or IMF management.}

\begin{abstract}
High household wealth is often cited as a key source of strength and resilience of the Italian economy. This paper documents the changes in the Italian household sector's financial wealth over the past two decades, by constructing the matrix of bilateral financial sectoral exposures. Both in absolute terms and relative to income, the Italian household sector is wealthier than most euro area peers. A sizable fraction of this wealth is held by the rich and upper middle classes, with a notable capacity to absorb shocks. Households have become increasingly exposed to the financial sector, which in turn is exposed to the highly indebted real and government sectors. The paper then simulates different financial shocks to gauge the ability of different sectors to absorb losses. Simple illustrative calculations are presented for a fall in the value of government bonds as well as for bank bail-ins versus bailouts.

JEL Classification Numbers: G11, G32, G33
\end{abstract}

Keywords: financial linkages, flow of funds, balance sheet analysis, bail-in, bailout.

Author's E-Mail Address: dgarciamacia@imf.org

\footnotetext{
${ }^{1}$ This paper benefited from comments by Majid Bazarbash, Nazim Belhocine, Rishi Goyal, Alvar Kangur, Valentina Michelangeli, Diarmuid Murphy, Mahmood Pradhan, Mehdi Raissi, Concetta Rondinelli, Miguel Segoviano, and other colleagues at seminars at the Bank of Italy and the IMF. David Velazquez-Romero provided research assistance.
} 
Abstract

I. INTRODUCTION

II. Data AND ACCounting Method

III. SECTORAL FINANCIAL EXPOSURES IN ITALY

IV. SimUlating THE IMPACT OF FinANCIAL SHOCKS

V. THREE IlLUSTRATIVE SHOCK SCENARIOS

VI. DISTRIBUTIONAL IMPACT

VII. CONCLUSION

REFERENCES

FiguRES

1. Average Net Household Wealth by Decile, 2014

2. Net Financial Assets by Sector

3. Select Sectoral Financial Exposures

4. Distribution of Household Assets by Household Wealth, 2016:Q4

5. Household Financial Asset Portfolio by Wealth, 2016:Q4

\section{TABLES}

1. Grouping of Sectors

2. Sectoral Financial asset Exposures, 2017:Q3

3. Sectoral Financial Asset Exposures, 2017:Q3

4. Impact of a Government Bond Value Shock

5. Impact of a Bank Bail-in

6. Impact of a Bank Bailout

7. Impact of Bank Shocks, Recapitalized Banks Counterfactual

8. Impact of Financial Shocks by Household Wealth Decile

\section{APPENDICES}

I. Identification of Sectoral Linkages in the Data

II. Financial Exposures over Time

III. Estimation of the Impact of Shocks

IV. Bank Shock Counterfactual Simulations 


\section{INTRODUCTION}

Italian household wealth is high by international standards. Total net household wealth at end-2013 was estimated at over $€ 9$ trillion, or 5 $\frac{1}{2}$ times GDP. Average wealth per household exceeds $€ 350,000$ and per capita is about $€ 150,000$ (Bank of Italy, 2014). As a percent of disposable income, it is higher than in several euro area peers, such as Austria, Finland, France, Germany and Luxembourg, although it is below those of Belgium and the Netherlands. The middle and upper segments of the distribution are particularly wealthy compared to the euro area average, both as a share of income and in absolute terms (Figure 1). Real assets - principally dwellings — constitute almost two thirds of total net wealth, while the rest are financial assets - mostly cash and deposits, shares, and insurance reserves.

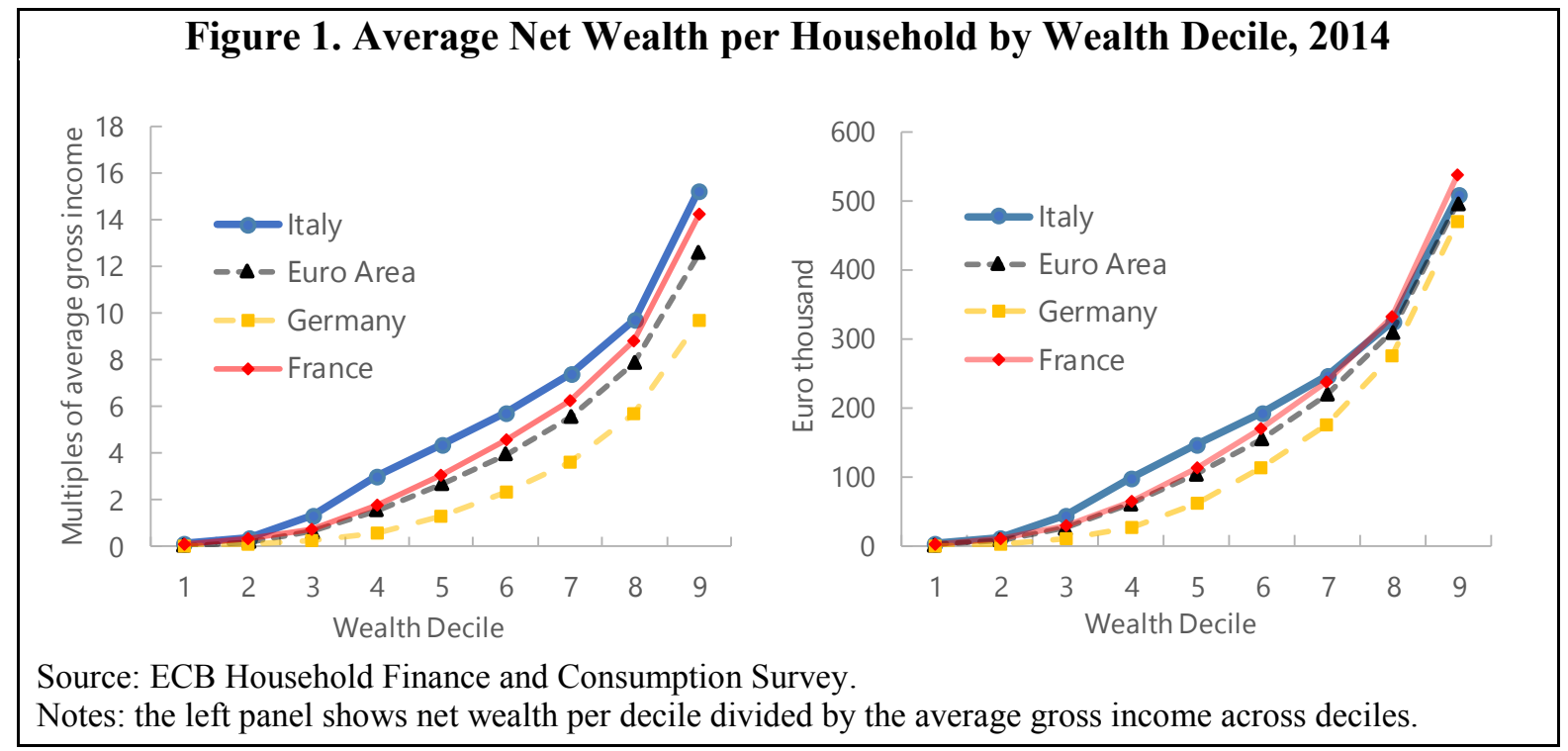

High net wealth of the household sector contrasts with balance sheet weaknesses of other sectors. Sectoral net financial positions in Italy display much larger imbalances than the Euro Area aggregate (Figure 2). Households stand out for their large positive balances, but the government features very negative financial wealth. The position of non-financial corporations is also very negative, but more in line with the Euro Area aggregate. Although real net household wealth has declined since the onset of the Global Financial Crisis (GFC), sectoral imbalances have tended to widen.

While high household net wealth or savings are a key strength of the Italian economy, negative financial wealth positions in other sectors could signal financial vulnerabilities. As a general matter, deeply indebted sectors can hit financial constraints and be a source of contagion to other sectors. Indeed, the literature on sectoral fund flows has long emphasized the financial non-neutrality of sectoral limits (e.g., Poterba (1987) documents the lack of a "corporate veil"). Understanding the transmission of shocks across sectors and their ultimate impact on households requires information about the nature of inter-sectoral bilateral financial linkages. Shocks to the value of a given instrument issued by a given sector transmit to other sectors via direct asset exposures and via equity interlinkages. For example, a fall in the value of corporate debt can directly affect financial institutions holding that debt, and in turn transmit to households with claims on financial institutions. 


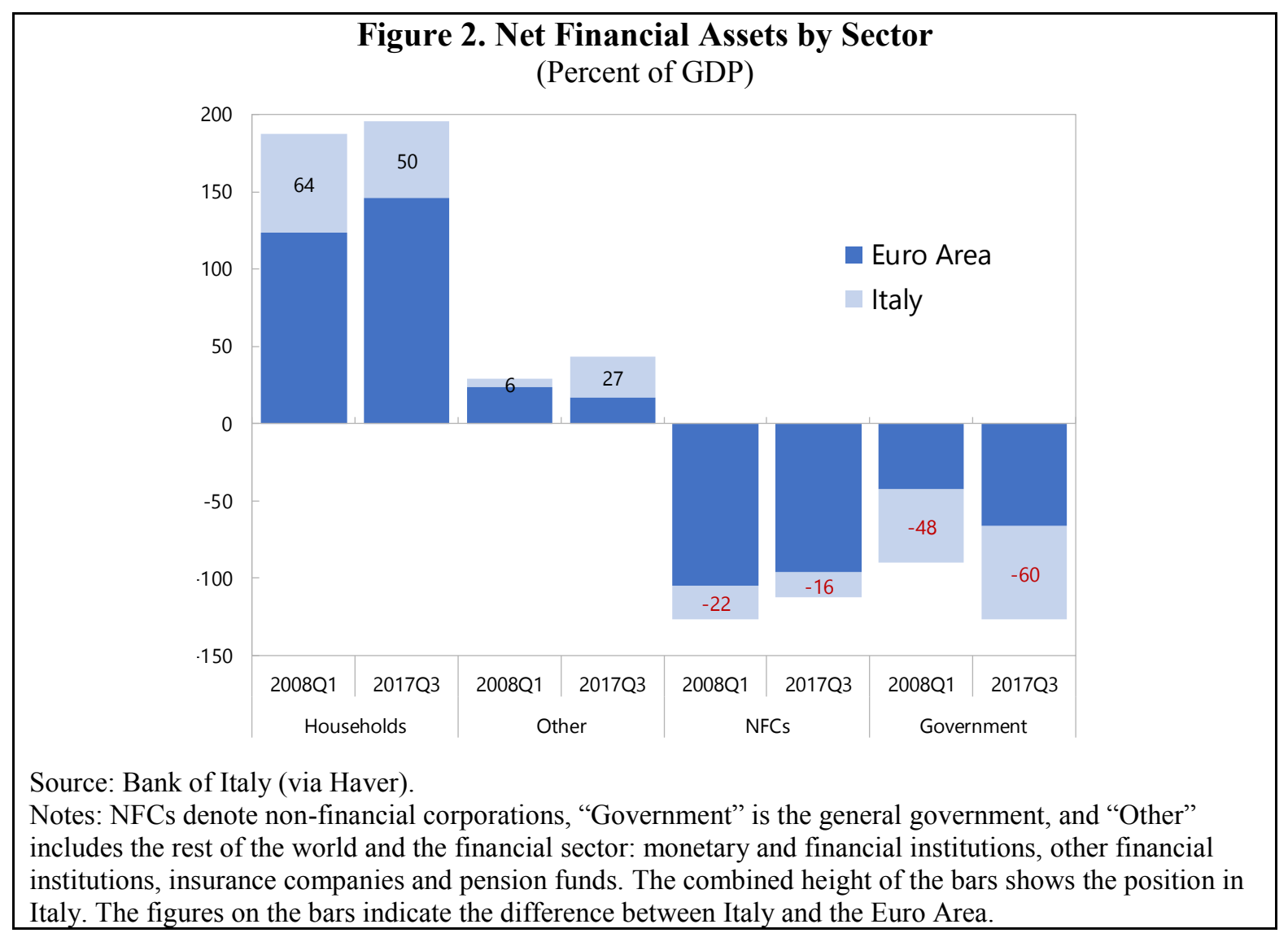

This paper constructs the matrix of bilateral financial sectoral exposures and simulates the impact of a series of illustrative financial shocks. Instrument-level inter-sectoral financial positions are inferred from the Bank of Italy's flow-of-funds data. The information on financial exposures is used illustratively to infer the impact across sectors of a fall in the value of government bonds, a bank bail-in, and a bank bailout. Household wealth survey data allow to pin down the impact of shocks across the wealth distribution.

\section{In brief, the key findings are as follows:}

- $\quad$ Since 1995, household wealth has increasingly been in insurance and pension fund assets and the rest of the world. Households' direct exposure to the government has declined, although it is now intermediated by financial institutions. Government liabilities have been increasingly funded by the rest of the world and financial institutions, with an important contribution from the Bank of Italy in recent years, reflecting the ECB's quantitative easing. Since the GFC, non-financial corporate balance sheets have shrunk, especially due to households withdrawing their investments. International financial diversification has slowed down.

- $\quad$ Financial wealth, and in particular risky assets, are concentrated at the upper end of the distribution. According to the Survey on Household Income and Wealth of the Bank of Italy, the top two household wealth deciles accumulate more than two thirds 
of financial wealth, and an even larger proportion of equity and non-secured debt. Less wealthy households own almost all their financial wealth in the form of insured bank deposits.

- A fall in the value of government bonds directly affects the financial sector and indirectly households. The Bank of Italy, private monetary financial institutions (MFIs), insurance and pension funds, and the rest of the world bear sizable balance sheet losses. However, as private financial institutions are ultimately owned by other sectors, primarily domestic and foreign households, these households - especially at the upper end of the wealth distribution - bear the brunt of the losses. Given the healthy financial position of households, together with the concentration of financial assets in wealthy households, the real impact of the shock should be manageable.

- A bank bail-in is more successful than a bailout in transmitting part of the shock to the rest of the world. In a bail-in scenario, the burden of bank debt restructuring is shared by domestic and foreign households, as those are the ultimate holders of MFI equity and bonds. Here too, the burden falls mostly on the top wealth deciles.

- $\quad$ However, in a bailout, the government would transfer resources to the wealthiest households and to the rest of the world. After a bailout, the top decile is less affected as a share of its financial wealth than the upper-middle range of the wealth distribution. From a simple arithmetic consideration, bailout interventions add to public debt, in turn imposing costs via taxes on labor income (that fall more evenly across the distribution than the wealth effects). Their countercyclical implications too are weak-as wealthier households have a lower marginal propensity to consume. These costs need to be balanced against other considerations for bailouts, including financial stability. Recapitalizing banks could help alleviate the need for, and cost of, a bailout.

Through this simple accounting exercise based on balance sheet exposures, the paper makes transparent some of the tradeoffs involved in the absorption of financial shocks. The exercise abstracts from the real effects of shocks, potential correlation across asset prices - other than equity values-portfolio reallocation in response to shocks, contagion across individual banks, or adjustment dynamics. In that regard, it is partial, as are other analyses in this literature as noted below. Policy decisions, particularly regarding bail-ins and bailouts, must take a comprehensive view and consider all transmission channels. Yet, the balance-sheet analysis is sufficient to unambiguously show that the Italian household sector, and particularly households at the upper end of the distribution, have ample capacity to absorb plausible financial shocks. Government intervention aimed at mitigating this absorption would be fiscally costly and ultimately of a regressive nature.

The literature has explored sectoral financial linkages in various contexts. Doepke and Schneider (2006) study the financial impact of inflation shocks across US sectors and over the income distribution. Castrén and Kavonius (2009) construct the financial exposures matrix for the Euro Area with a similar method as this paper. Heipertz et al. (2017) estimate sectoral valuation linkages with security-level French data. Koijen et al. (2018) focus on the impact of QE by the ECB on sectoral portfolios. Cortes et al. (2018) develop a method to 
estimate contagion across sectors within the financial system. IMF (2015) reviews the use of balance sheet analysis at the Fund.

This paper contributes to the literature by estimating the direct, indirect, and distributional impact of specific valuation shocks. Castrén and Kavonius (2009) use data with coarser sectoral information. More importantly, they only consider a (small) finite number of equity impact rounds, while this paper simulates the full equity impact. Estimating the full equity impact is necessary given sizable bi-directional equity holdings between sectors. It is also crucial when calculating distributional effects, as wealthier households invest disprorportionately more in equity than in bonds. Heipertz et al. (2017) have access to more disaggregated data, but they do not focus on bank restructuring scenarios. ${ }^{2}$

\section{Data ANd ACCounting Method}

Flow-of-funds data provide information on sectoral financial exposures. The Bank of Italy publishes quarterly flow-of-funds data (sourced via Haver) covering the period 1995:Q1-2017:Q3. This dataset contains information, for each economic sector, on the stock positions in different financial instruments (assets and liabilities). The classification follows the European System of Accounts (2010). Table 1 lists the disaggregation of sectors in the data, as well as the simplified grouping applied in this paper.

\begin{tabular}{|lc|}
\hline \multicolumn{2}{|c|}{ Table 1. Grouping of Sectors } \\
Original sectors in the data & Coding \\
\hline Nonfinancial Corporations & NFC \\
\hline Monetary Financial Institutions Excluding Central Bank & MFI \\
\hline Bank of Italy & BOI \\
\hline $\begin{array}{l}\text { Other Financial Intermediaries Excluding non-MMF Investment Funds } \\
\text { Non-MMF Investment Funds } \\
\text { Financial Auxiliaries }\end{array}$ & OFI \\
\hline $\begin{array}{l}\text { Insurance Companies } \\
\text { Pension Funds }\end{array}$ & INP \\
\hline $\begin{array}{l}\text { Central Government } \\
\text { Local Government } \\
\text { Social Security Funds }\end{array}$ & GOV \\
\hline Households and Nonprofit Institutions Serving Households & HH \\
\hline Rest of the World & RoW \\
\hline
\end{tabular}

The data are used to construct a matrix of cross-sectoral bilateral financial exposures. A given entry $(i, j)$ in the matrix contains the financial asset holdings of sector $i$ invested in sector $\mathrm{j}$, or equivalently the liabilities of sector $\mathrm{j}$ with respect to sector $\mathrm{i}$. Appendix I describes the steps and necessary assumptions to infer sectoral exposures from the Italian flow-offunds data. The dataset only includes financial assets. A sector can have a non-zero net

\footnotetext{
${ }^{2}$ Hüser et al. (2017) study the implications of a bail-in for different types of creditors of the largest euro area banks. Gourinchas et al. (2017) model wealth transfers among monetary union members in a bailout.
} 
financial asset balance, which should be matched by an opposite net balance of real assets or by own-sector net worth (in the case of BOI, GOV, HH and RoW).

Survey data allow to zoom into household financial exposures as a function of household wealth. The Bank of Italy's Survey on Household Income and Wealth (2016) contains financial information (and sample weights) for a representative sample of about 7,000 households. These data are used to calculate the distribution of stock positions and the impact of financial shocks across household wealth deciles. The ECB's Household Finance and Consumption Survey (2014) allows to compare against the distribution in other euro area economies.

\section{SECTORAL FinANCIAL EXPOSURES IN ITALY}

Table 2 is the matrix of sectoral financial exposures in Italy in 2017:Q3, expressed as a percent of GDP. For example, non-financial corporates (NFC) own financial assets of monetary financial institutions (MFI) worth 14 percent of GDP, and equivalently MFIs have financial liabilities of 14 percent of GDP with respect to NFCs. The rightmost column shows the net financial asset (NFA) position of each sector, equal to total assets minus total liabilities. ${ }^{3}$

\begin{tabular}{|c|c|c|c|c|c|c|c|c|c|c|}
\hline \multicolumn{11}{|c|}{$\begin{array}{l}\text { Table 2. Sectoral Financial asset Exposures, 2017:Q3 } \\
\text { (Percent of GDP) }\end{array}$} \\
\hline & NFC & MFI & BOI & OFI & INP & GOV & HH & RoW & Tot. As. & NFA \\
\hline NFC & & 14 & 7 & 1 & 2 & 6 & 5 & 27 & 61 & -112 \\
\hline MFI & 54 & & 5 & 13 & 1 & 37 & 37 & 23 & 170 & 0 \\
\hline BOI & 0 & 16 & & 0 & 0 & 22 & 0 & 13 & 53 & 6 \\
\hline OFI & 11 & 18 & 2 & & 0 & 8 & 4 & 26 & 69 & 27 \\
\hline INP & 4 & 3 & 1 & 3 & & 20 & 0 & 25 & 55 & -2 \\
\hline GOV & 11 & 5 & 1 & 4 & 1 & & 4 & 4 & 30 & -124 \\
\hline НH & 54 & 64 & 19 & 16 & 50 & 14 & & 30 & 247 & 196 \\
\hline RoW & 39 & 50 & 12 & 6 & 3 & 47 & 1 & & 157 & 8 \\
\hline Tot. Liab. & 174 & 170 & 47 & 42 & 56 & 154 & 51 & 149 & 843 & \\
\hline
\end{tabular}

The distribution of sectoral financial linkages is highly non-uniform. Table 2 shows that NFCs have a very negative NFA position, with liabilities mainly to MFIs and households. The mirror image is the extremely positive NFA of households, with assets predominantly in MFIs, NFCs and insurance and pension funds (in this order). The government is very indebted, mostly owing to the financial sector and the rest of the world. The Bank of Italy is an important creditor of the government, reflecting the Eurosystem's implementation of QE via its local branch. However, the public sector also holds a significant amount of assets in

\footnotetext{
${ }^{3}$ Summing up all sectors, total financial assets equal total financial liabilities, i.e., the system is closed, as it includes the position of the rest of the world vis-à-vis Italy.
} 
private sectors, especially NFCs, suggesting it has room to divest and cut its gross liabilities. MFIs are (not surprisingly) financially balanced, with assets in NFCs and the government, and liabilities to households and the rest of the world.

The portfolio composition is visualized expressing financial exposures as a share of total sector assets (Table 3). This nets out the effect of a sector's balance sheet size. One key message is that MFIs and insurance and pension funds are relatively more exposed to government assets, which indirectly exposes their creditors and/or shareholders, such as households and NFCs.

\begin{tabular}{|lrrrrrrrr|r|}
\hline \multicolumn{7}{|c|}{ Table 3. Sectoral Financial Asset Exposures, 2017:Q3 } \\
(Percent of sector assets) \\
NFC & MFI & BOI & OFI & INP & GOV & HH & RoW & Total \\
\hline NFC & & 23 & 11 & 2 & 3 & 10 & 9 & 43 & 100 \\
MFI & 32 & & 3 & 7 & 1 & 22 & 22 & 14 & 100 \\
BOI & 1 & 31 & & 1 & 0 & 42 & 0 & 25 & 100 \\
OFI & 16 & 27 & 3 & & 0 & 11 & 6 & 37 & 100 \\
INP & 7 & 5 & 1 & 5 & & 36 & 0 & 46 & 100 \\
GOV & 36 & 17 & 3 & 12 & 2 & & 14 & 15 & 100 \\
HH & 22 & 26 & 8 & 6 & 20 & 6 & & 12 & 100 \\
RoW & 25 & 32 & 8 & 4 & 2 & 30 & 1 & & 100 \\
\hline All & $\mathbf{2 1}$ & $\mathbf{2 0}$ & $\mathbf{6}$ & $\mathbf{5}$ & $\mathbf{7}$ & $\mathbf{1 8}$ & $\mathbf{6}$ & $\mathbf{1 8}$ & $\mathbf{1 0 0}$ \\
Source: Bank of Italy (via Haver). & & & & & & & & \\
Notes: The last row shows the portfolio composition for the aggregate of all sectors. & & \\
\hline
\end{tabular}

Next, the evolution of sectoral exposures over five data snapshots is explored (Appendix II): (i) beginning of the sample: 1995:Q1; (ii) pre deployment of the euro: 2001:Q4; (iii) pre GFC: 2008:Q1; (iv) pre Outright Monetary Transactions program announcement: 2012:Q2; and (v) end of the sample: 2017:Q3.

The sum of financial assets in all sectors doubled from 1995:Q1 to 2017:Q3 (from 418 to 843 percent of GDP). This reflects the process of European financial integration, as well as the increase in financial intermediation. Appendix II contains the full matrix of bilateral exposures at each point in time, while Figure 3 reports key takeaways:

- $\quad$ The first panel of Figure 3 shows the growing importance of foreign liabilities, as well as the diversification of households and other financial institutions (OFIs) towards foreign asset holdings, peaking at the time of Euro accession. Yet, the diversification process has slowed down, and the degree of home bias remains elevated.

- $\quad$ The second panel shows that households shifted their asset portfolio away from the government and into insurance and pension funds. Their asset holdings in MFIs peaked in the run-up to the GFC, but receded thereafter. The GFC also halted the accumulation of NFC liabilities, mostly due to a decline in household investment. 
- $\quad$ On the other hand, the government became more reliant on MFI funding after the GFC, when some international creditors retreated. Since 2012, the Bank of Italy stepped in as a major creditor through the implementation of monetary policy.

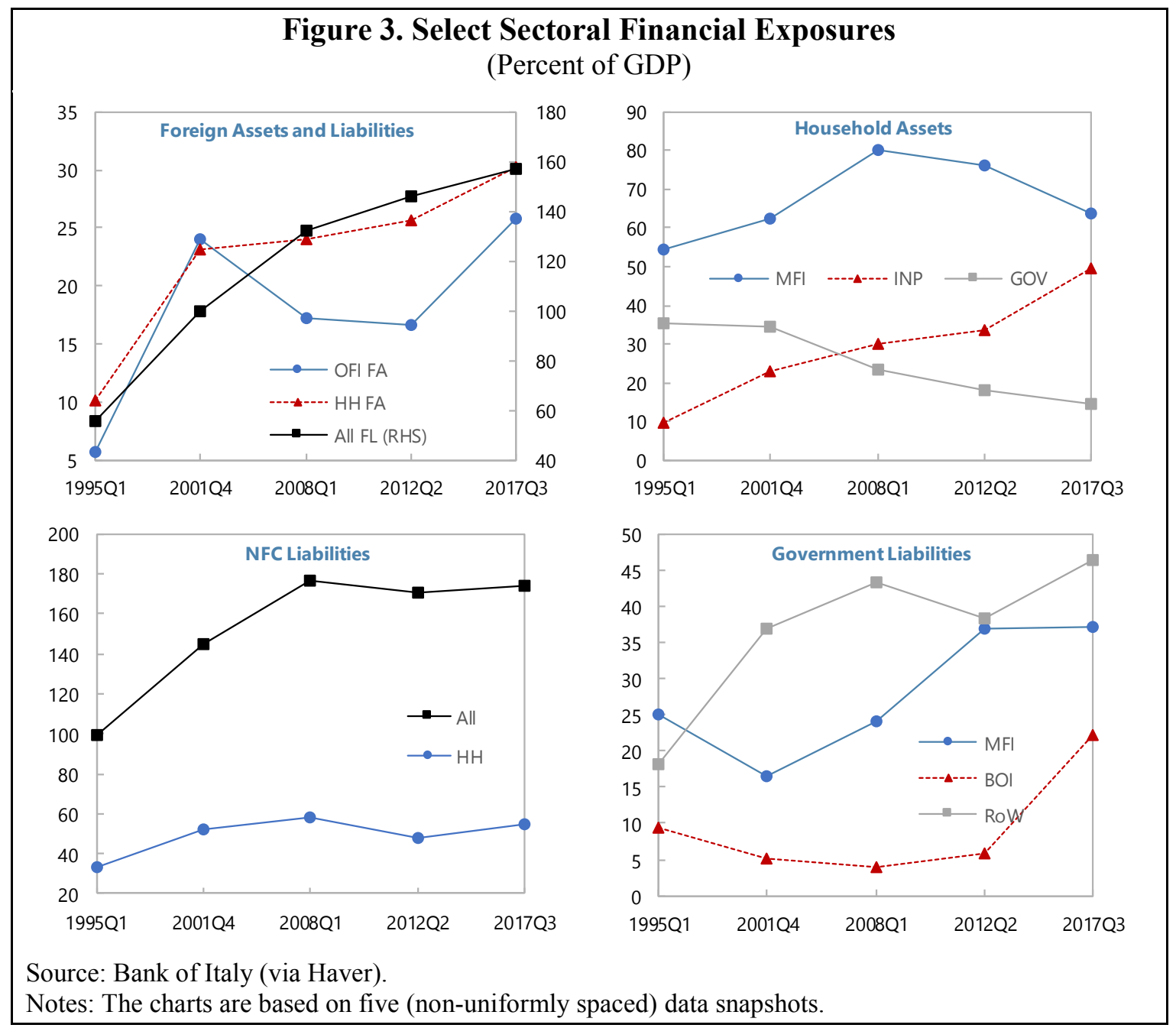

\section{Simulating The ImPaCt OF Financial SHOCKS}

The sectoral exposures matrix is used to simulate the impact of financial shocks across sectors. This section describes how to calculate the impact of different shocks on sectoral net financial assets, whereas the next section discusses the results of each shock scenario. A valuation shock to an instrument issued by a particular sector is considered first. A valuation shock has a direct impact on other sectors' NFA positions given by these sectors' holdings of the instrument suffering the shock. But shocks also have an indirect impact given by intersectoral equity linkages. Since the only sectors that are the ultimate equity owners are households, the government, the Bank of Italy and the rest of the world, they end up absorbing the totality of the NFA impact of a shock. For the rest of sectors, the final NFA impact is zero, as any direct impact is compensated by an equal change in equity liabilities to either HH, GOV, BOI or RoW. Appendix III describes the formal expressions to obtain the direct, indirect, and total shock impacts. 
The case of a bank bail-in and bailout are slightly different from a straightforward valuation shock. These two scenarios assume that the value of other sectors' assets in a set of MFIs decline. In particular, the bail-in case assumes that all the equity of affected MFIs is wiped out and all their bonds are converted into equity, at a conversion rate of 50 percent. ${ }^{4}$ For simplicity, it also assumes that no public resolution funds are used and that other (nonbond) debtholders are not affected. Since equity is wiped out, the indirect equity impact for MFIs is zero (unlike in the valuation shock case above).

The difference in a bailout scenario is the government's intervention. The government makes a transfer to compensate MFI bondholders for any losses-which are assumed to be equal to those in a bail-in. Only shareholders are wiped out. Since among the troubled bank bondholders are other MFIs, their corresponding share of the government transfer increases their equity value. Hence, the indirect equity effect for MFIs is in this case negative, equal to (minus) the government transfer to troubled-bank bondholder MFIs. The balance sheet counterpart of the negative equity impact for MFIs is a positive equity impact for their ultimate shareholders.

As noted above, such exercises explore the impact on wealth, rather than on economic activity. Negative shocks to household and government wealth could depress private and public consumption, while shocks to corporate or bank balance sheets could hinder investment. ${ }^{5}$ Instead, the focus of the paper is on gauging the households' shock or loss absorption capacity, given its importance for financial stability in Italy. Moreover, for simplicity, the simulations abstract from potential correlated price changes in other securities-beyond the change in equity values, portfolio reallocation after the shocks (e.g., prompted by regulatory constraints), or adjustment dynamics.

\title{
V. Three Illustrative SHOCK SCENARIOS
}

\begin{abstract}
A fall in the value of government bonds directly affects the financial sector and indirectly households (Table 4). A shock equivalent to a 10 percent decline in the value of government debt (e.g., owing to an increase in market perception of risk or nominal interest rates) is considered. ${ }^{6}$ This is akin to a sizable shock. ${ }^{7}$ The direct impact, given by government bond exposures, is concentrated on the financial sector, including MFIs, the Bank of Italy and insurance and pension funds, as well as on the rest of the world. However, once equity
\end{abstract}

\footnotetext{
${ }^{4}$ This was approximately the conversion rate applied to Monte dei Paschi junior debtholders in its July 2017 bailout - the most recent one that occurred in Italy. Combined with the equity wipe out, the value of affected liabilities assumed here is above the Minimum Required Eligible Liabilities (MREL) mandated by the Bank Recovery and Resolution Directive (BRRD) to contribute public funds to a bail-in. Appendix IV considers the alternative assumption of a zero conversion rate.

${ }^{5}$ Yet, financial shocks concentrated on wealthy households, such as the ones modeled in this paper, are not likely to induce a large consumption response, given their smaller marginal propensity to consume.

${ }^{6}$ This is equivalent to an increase in yields of around 220 basis points, given the current duration of Italian outstanding government debt of 4.88 years (source: Bloomberg). For comparison, this is about 1.5 times the increase Italy experienced in late May 2018.

${ }^{7}$ Since the analysis is purely static, there is no need to specify the persistence of the shock.
} 
linkages are considered, the sector with a larger total NFA decline is the rest of the world, followed by households. The impact on households as a fraction of GDP is non-negligible at about 4 percent of GDP, but only 2 percent as a fraction of their NFA. Government liabilities diminish by an equal amount, which raises the government's NFA position.

Next, a bank bail-in is compared to a bank bailout scenario. The two scenarios simulate a bank restructuring affecting a bank (or set of banks) constituting 10 percent of MFI liabilities. This implies a 10 percent reduction in the value of MFI equity liabilities and a 5 percent reduction in the value of their bond liabilities (at a 50 percent conversion rate). This is also a very sizable shock. In the case of a bailout, bond losses are fully compensated by the government, as explained in the previous section.

\begin{tabular}{|lrrrr|}
\hline \multicolumn{5}{|c|}{ Table 4. Impact of a Government Bond Value Shock } \\
(Percent of GDP)
\end{tabular}

A bank bail-in mostly affects households and the rest of the world (Table 5). This applies to both the direct and the total NFA impact. In fact, almost half of a bail-in's impact is absorbed by the rest of the world, which should mitigate the shock's damage to the domestic real economy. The impact on households is slightly over 1 percent of GDP, or $1 / 2$ percent of the households' NFA. The NFA of MFIs increases as their liabilities to other sectors are reduced. 


\begin{tabular}{|lrrrr}
\hline \multicolumn{5}{c}{$\begin{array}{c}\text { Table 5. Impact of a Bank Bail-in } \\
\text { (Percent of GDP) }\end{array}$} \\
& NFA & \multicolumn{2}{c}{$\begin{array}{c}\text { direct impact } \\
\text { equity impact }\end{array}$} & $\Delta$ NFA \\
\hline NFC & -112 & -0.2 & 0.2 & $\mathbf{0 . 0}$ \\
MFI & 0 & 2.3 & 0.0 & $\mathbf{2 . 3}$ \\
BOI & 6 & -0.1 & 0.0 & $\mathbf{- 0 . 1}$ \\
OFI & 27 & -0.1 & 0.1 & $\mathbf{0 . 0}$ \\
INP & -2 & -0.1 & 0.1 & $\mathbf{0 . 0}$ \\
GOV & -124 & -0.1 & 0.0 & $\mathbf{- 0 . 1}$ \\
HH & 196 & -0.9 & -0.3 & $\mathbf{- 1 . 2}$ \\
RoW & 8 & -0.7 & -0.1 & $\mathbf{- 0 . 9}$ \\
\hline
\end{tabular}

Source: Bank of Italy (via Haver) and staff calculations.

Notes: Assuming banks constituting 10 percent of MFI assets are bailed in. All their equity is wiped out and all their bonds converted to equity, at a 50 percent conversion rate.

A bailout is less successful in sharing the impact with the rest of the world (Table 6 ). The burden of a bailout falls mostly on the government, at over $1 \frac{1}{2}$ percent of GDP, which worsens an already vulnerable financial position, and secondarily on domestic households. While foreign shareholders of domestic MFIs absorb a small fraction of the shock, the government ends up transferring resources to foreign bondholders. Overall, foreign absorption of the shock falls by 75 percent compared to a bail-in.

\begin{tabular}{|lrrrr|}
\hline \multicolumn{5}{c|}{ Table 6. Impact of a Bank Bailout } \\
\multicolumn{5}{c}{ Percent of GDP } \\
NFA & direct impact & equity impact & SNFA \\
\hline NFC & -112 & -0.2 & 0.2 & $\mathbf{0 . 0}$ \\
MFI & 0 & 2.9 & -0.6 & $\mathbf{2 . 3}$ \\
BOI & 6 & 0.0 & 0.0 & $\mathbf{0 . 0}$ \\
OFI & 27 & 0.0 & 0.0 & $\mathbf{0 . 0}$ \\
INP & -2 & 0.0 & 0.0 & $\mathbf{0 . 0}$ \\
GOV & -124 & -1.7 & 0.0 & $\mathbf{- 1 . 6}$ \\
HH & 196 & -0.6 & 0.2 & $\mathbf{- 0 . 4}$ \\
RoW & 8 & -0.3 & 0.1 & $\mathbf{- 0 . 2}$ \\
Source: Bank of Italy (via Haver) and staff calculations. & & \\
Notes: Assuming banks constituting 10 percent of MFI assets are bailed out. All their equity is wiped out, \\
and the government compensates bondholders for 50 percent of their bond holdings value. \\
\hline
\end{tabular}

Recapitalizing banks would significantly reduce the public cost of a bailout (Table 7). Italian banks' tier 1 capital ratios remain below the euro area average (ECB Supervisory Banking Statistics). A 50 percent increase in the aggregate capital to assets ratio of MFIs would cut the public cost of a bailout by a third, and double the foreign absorption rate. On the other hand, the recapitalization would slightly increase the impact of a bail-in on domestic households, as these tend to hold a disproportionate amount of equity relative to 
bonds compared to foreigners. Yet, while this exercise takes the financial shock as given, recapitalizing banks could also limit their risk-taking, potentially reducing the probability and size of shocks.

The above bank shock simulations are subject to a number of caveats. First, the conversion rate of bonds into equity in a bail-in usually depends on circumstance. Appendix IV presents results assuming a zero conversion rate. Second, smaller banks, which feature more vulnerable balance sheets and are more likely to be restructured, are also disproportionately owned by domestic households. Taking this into account would reduce the subsidy to the rest of the world associated with a bailout. Third, unlike a bail-in, a bailout may prevent contagion to other MFIs, potentially preventing detrimental knock-on effects on financial stability and investment. Finally, the bail-in and bailout scenarios must be interpreted as illustrative polar cases, since actual experiences of bank restructuring typically contain elements of both. 


\begin{tabular}{|c|c|c|c|c|}
\hline \multicolumn{5}{|c|}{$\begin{array}{c}\text { Table 7. Impact of Bank Shocks, Recapitalized Banks Counterfactual } \\
\text { Percent of GDP }\end{array}$} \\
\hline & \multicolumn{2}{|c|}{ Bail-in } & \multicolumn{2}{|c|}{ Bailout } \\
\hline & baseline & recapitalized & baseline & recapitalized \\
\hline NFC & \multicolumn{2}{|c|}{0.0} & \multicolumn{2}{|c|}{0.0} \\
\hline MFI & \multicolumn{2}{|c|}{2.3} & \multicolumn{2}{|c|}{2.3} \\
\hline BOI & \multicolumn{2}{|c|}{-0.1} & \multicolumn{2}{|c|}{0.0} \\
\hline OFI & \multicolumn{2}{|c|}{0.0} & \multicolumn{2}{|c|}{0.0} \\
\hline INP & \multicolumn{2}{|c|}{0.0} & \multicolumn{2}{|c|}{0.0} \\
\hline GOV & \multicolumn{2}{|c|}{-0.1} & \multicolumn{2}{|c|}{-1.6} \\
\hline НH & \multicolumn{2}{|c|}{-1.2} & \multicolumn{2}{|c|}{-0.4} \\
\hline RoW & \multicolumn{2}{|c|}{-0.9} & \multicolumn{2}{|c|}{-0.2} \\
\hline \multicolumn{5}{|c|}{$\begin{array}{l}\text { Source: Bank of Italy (via Haver) and staff calculations. } \\
\text { Notes: the table shows the total NFA change after a bank bail-in and a bailout under two different } \\
\text { assumptions. Column "baseline" is based on the actual level of bank capital (like Tables } 5 \text { and } 6 \text { ). Column } \\
\text { "recapitalized" assumes a } 50 \text { percent higher MFI capital to total assets ratio, with the increase } \\
\text { proportionally distributed across shareholder sectors. }\end{array}$} \\
\hline
\end{tabular}

\section{Distributional IMPACT}

\section{Survey data allow to further decompose the impact of shocks absorbed by each} household wealth group. This section documents stylized facts of the financial wealth distribution for different financial instruments. Next, it uses this information to estimate how the burden of the financial shocks considered in the previous section is shared across household wealth deciles.

Financial wealth is concentrated at the top of the distribution (Figure 4). Households at the top 20 percent of the wealth distribution hold 69 percent of financial wealth. This is particularly the case for risky assets, such as equity holdings (93 percent at the top 20), and to a lesser extent for bank bonds (79 percent at the top 20). Government bonds are distributed in line with total financial wealth.

Wealthier households hold riskier financial instruments (Figure 5). The financial portfolio of less-wealthy households is almost entirely constituted by (insured) bank deposits, so they are not directly affected by government bond or bank financial shocks. Wealthier households, with a higher capacity to absorb losses, invest proportionally more in equity and non-secured fixed income instruments. Yet, most of their financial wealth is also in safe assets. 


\section{Figure 4. Distribution of Household Assets by Household Wealth, 2016:Q4 (Percentage points)}

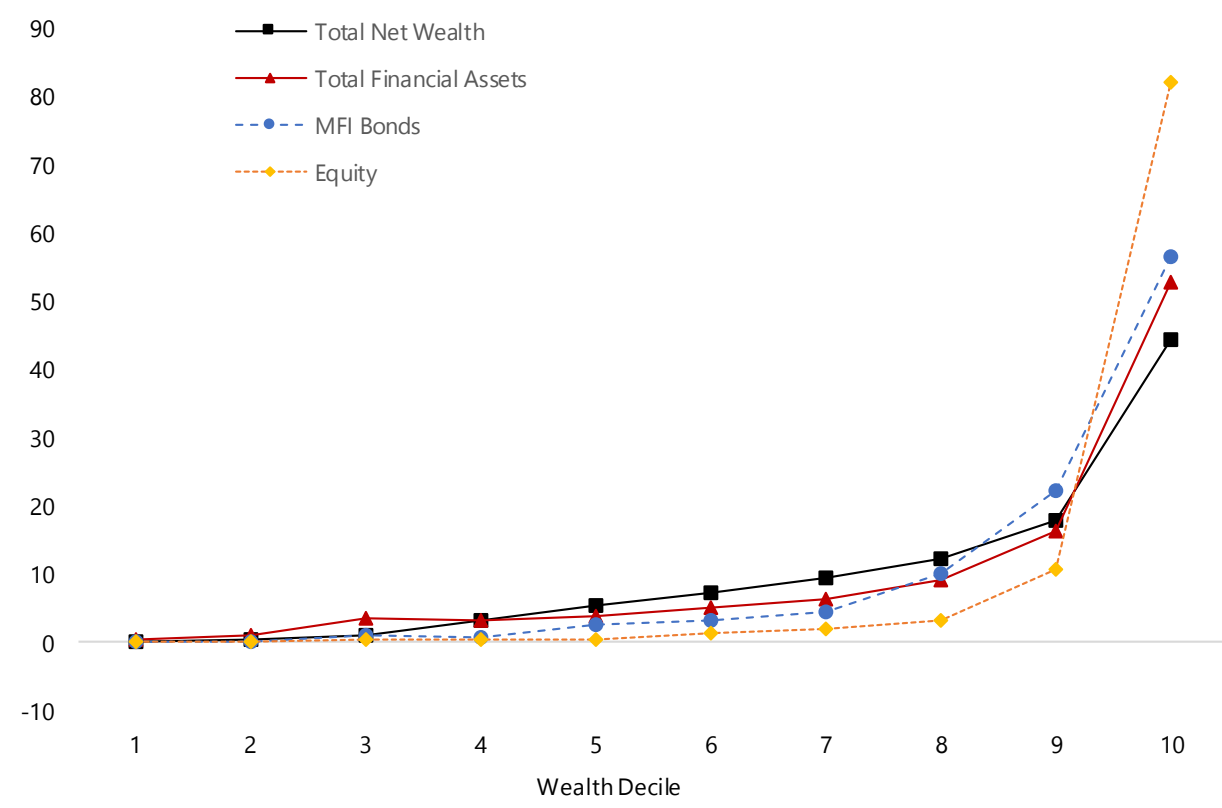

Source: Bank of Italy's Survey on Household Income and Wealth.

Notes: Perfect equality would correspond to a flat line across deciles at 10 percent. Equity includes shares as well as equity funds and ETFs.

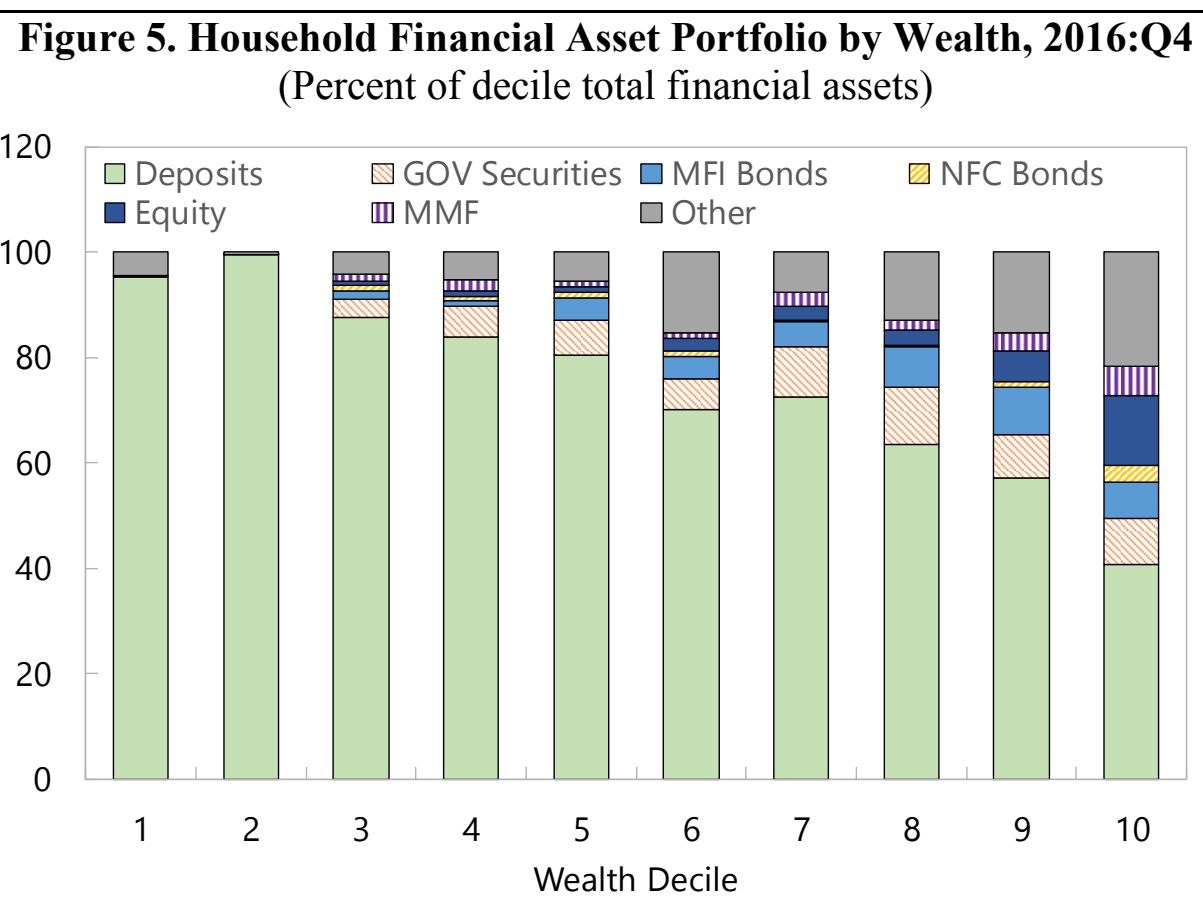

Source: Bank of Italy's Survey on Household Income and Wealth.

Notes: MMF are money-market funds. Equity includes shares and equity mutual funds. The category 'Other" consists mostly of mutual funds which are neither equity funds nor MMF, as well as of pension funds. 
As a result, wealthy households absorb most of the financial losses after a government bond shock or a bail-in. Table 8 shows the impact of the three financial shocks by household decile, expressed both in euros per household and as a percentage of decile total financial assets, together with the average net real wealth and gross financial assets of each decile (first two columns). Wealthier households are more affected by financial shocks, both in absolute terms as and as a percentage of their financial assets, especially for a government bond shock (where the indirect equity impact is relatively more important). Hence, the social welfare effect of such shocks is smaller than their wealth effect.

On the contrary, the cost of a bailout is less concentrated in wealthier households. In fact, households at the top decile of the wealth distribution contribute less as a percentage of their financial assets than the next three deciles. This is because in a bailout the government compensates MFI bondholder sectors which are ultimately owned by wealthy households, such as other MFIs, OFIs and NFCs, generating a positive indirect equity impact. Moreover, given that wealthier households have a lower marginal propensity to consume out of income shocks, the fiscal expansion associated with a bailout would probably lead to a meager GDP multiplier. ${ }^{8}$

\begin{tabular}{|c|c|c|c|c|c|c|c|c|}
\hline \multirow[b]{3}{*}{ Decile } & \multicolumn{7}{|c|}{$\begin{array}{l}\text { Table 8. Impact of Financial Shocks by Household Wealth Decile } \\
\text { (Percentage points) }\end{array}$} & \\
\hline & \multicolumn{5}{|c|}{ euros per $\mathrm{HH}$} & \multicolumn{2}{|c|}{$\%$ of decile fin. assets } & \\
\hline & Wealth & Fin. As. & Gov. bond & Bail-in & Bailout & Gov. bond & Bail-in & \\
\hline 1 & $-1,584$ & 477 & 0 & 0 & 0 & -0.1 & 0.0 & 0.0 \\
\hline 2 & 3,326 & 2,438 & 0 & 0 & 0 & 0.0 & 0.0 & 0.0 \\
\hline 3 & 17,651 & 9,488 & -51 & -23 & -12 & -0.5 & -0.2 & -0.1 \\
\hline 4 & 65,334 & 8,486 & -76 & -18 & -8 & -0.9 & -0.2 & -0.1 \\
\hline 5 & 108,434 & 9,928 & -91 & -61 & -36 & -0.9 & -0.6 & -0.4 \\
\hline 6 & 146,859 & 13,849 & -183 & -92 & -46 & -1.3 & -0.7 & -0.3 \\
\hline 7 & 194,062 & 17,044 & -306 & -126 & -62 & -1.8 & -0.7 & -0.4 \\
\hline 8 & 254,080 & 24,771 & -504 & -277 & -149 & -2.0 & -1.1 & -0.6 \\
\hline 9 & 367,042 & 45,014 & $-1,260$ & -650 & -310 & -2.8 & -1.4 & -0.7 \\
\hline 10 & 914,511 & 146,949 & $-8,183$ & $-2,113$ & -511 & -5.6 & -1.4 & -0.3 \\
\hline total & 206,971 & 27,844 & $-1,066$ & -336 & -113 & -3.8 & -1.2 & -0.4 \\
\hline \multicolumn{9}{|c|}{$\begin{array}{l}\text { Source: Bank of Italy (Survey on Household Income and Wealth, and flow-of-funds data) and staff } \\
\text { calculations. }\end{array}$} \\
\hline \multicolumn{9}{|c|}{$\begin{array}{l}\text { Notes: The first column shows household total net wealth (including real assets), while the second one shows } \\
\text { gross financial assets. }{ }^{1} \text { The next three columns show the absolute impact absorbed by each decile in euros per } \\
\text { household, while the last three columns show the impact as a percentage of the decile's total gross financial } \\
\text { assets. The results assume that bank equity exposures are distributed as total equity exposures. }\end{array}$} \\
\hline \multicolumn{9}{|c|}{$\begin{array}{l}{ }^{1} \text { The average level of wealth and (especially) financial assets according to the Survey on Household Income } \\
\text { and Wealth (2016) is significantly lower than the } 2013 \text { aggregate reported by the Bank of Italy (see Section 1). } \\
\text { Beyond the year difference, this could be due to underreporting in the survey, especially at the right tail of the } \\
\text { wealth distribution, where financial assets in particular are concentrated. In any case, survey data are only used } \\
\text { to obtain the distribution. Financial wealth levels are from the flow of funds data. }\end{array}$} \\
\hline
\end{tabular}

\footnotetext{
${ }^{8}$ See, e.g., Arrondel et al. (2015) for an estimate of the marginal propensity to consume by wealth level in France.
} 


\section{Conclusion}

Italy's sectoral asset exposures stand out for their strong household net financial positions but also for the weakness of other sectors. The household sector has been increasing its net financial position by building assets in the financial sector, which in turn has been lending to the heavily indebted public and nonfinancial corporate sectors. Reflecting quantitative easing, in recent years, the Bank of Italy has also become heavily exposed to Italian government assets.

\section{An illustrative set of calculations reveals the diverse impact of financial shocks across} sectors. The purpose is to assess the loss absorption capacity of households rather than to fully specify the deleterious GDP and employment effects, which should also be considered in policy making. A fall in the value of government bonds impacts the financial sector and is ultimately absorbed by foreign and domestic households. The impact of a sizable loss in the value of government assets on net household wealth is relatively large but appears manageable, especially considering that it affects mostly the upper parts of the wealth distribution. Regarding the analysis of bank bail-ins and bailouts, although not a comprehensive assessment of all their implications, the contribution of the paper is to highlight a series of quantitatively relevant factors that are often not transparent in the policy debate. In the case of a bail-in, the overall impact on wealth is relatively small, and the impact on welfare is even smaller, considering its incidence is almost entirely at the top end of the wealth distribution. The degree of domestic absorption in a bank bail-in is much lower than in a bailout, in which the government in effect transfers resources to foreigners and thus bears the brunt of the loss in value. These costs will need to be passed on to the domestic taxpayer, and thus across the broader parts of the income and wealth distribution, given the heavy reliance on labor income and consumption taxes as opposed to wealth taxes. 


\section{REFERENCES}

Allen, Franklin and Douglas Gale, "Financial contagion”, Journal of Political Economy, $108,(2000)$.

Arrondel, Luc, Pierre Lamarche and Frédérique Savignac, "Wealth Effects on Consumption Across the Wealth Distribution: Empirical Evidence," ECB Working Paper 1817, (2015).

Bank of Italy, "Household Wealth in Italy in 2013", No. 69, (2014).

Castrén, Olli, and Ilja Kristian Kavonius, "Balance sheet interlinkages and macro-financial risk analysis in the euro area." ECB Working Paper No 1124, (2009).

Cortes, Fabio, Peter Lindner, Sheheryar Malik, and Miguel Angel Segoviano. "A comprehensive multi-sector tool for analysis of systemic risk and interconnectedness (SyRIN).” IMF Working Paper 18/14, (2018)

Doepke, Matthias, and Martin Schneider. "Inflation and the redistribution of nominal wealth." Journal of Political Economy 114, no. 6: 1069-1097, (2006).

Gourinchas, Pierre Olivier, Philippe Martin, and Todd Messer. "The Economics of Sovereign Debt, Bailouts and the Eurozone Crisis." Mimeo, (2017).

Heipertz, Jonas, Romain Ranciere, and Natacha Valla. "Domestic and international sectoral portfolios: Network structure and balance sheet effects.", NBER Working Paper 23572, (2017).

Hüser, Anne-Caroline, Grzegorz Hałaj, Christoffer Kok, Cristian Perales, and Anton van der Kraaij. "The systemic implications of bail-in: a multi-layered network approach." Journal of Financial Stability (2017).

Koijen, Ralph SJ, Francois Koulischer, Benoit Nguyen, and Motohiro Yogo, "Quantitative Easing in the Euro Area: The Dynamics of Risk Exposures and the Impact on Asset Prices." Banque de France Working Paper No 601, (2018).

International Monetary Fund, "Balance sheet analysis in Fund surveillance", IMF Policy Papers, (2015).

Poterba, James M., "Tax Policy and Corporate Saving, Brookings Papers on Economic Activity: 2”, pp. 455-515, Washington: Brookings Institution, (1987). 


\section{APPENDIX I. IDENTIFICATION OF SECTORAL LiNKAGES IN THE DATA}

This appendix describes the necessary assumptions to infer intersectoral exposures from Italian flow-of-funds data.

For some sector-instruments, such as government bonds, identifying the counterparty sector is straightforward - the government. If the counterparty sector of an instrument is reported as "other financial institutions", the assets are distributed between OFI and INP according to the relative total liabilities of these two sectors in that particular instrument. A similar assumption applies to instruments issued by MFIs when the data does not specify whether these are issued by the Bank of Italy or other MFIs (e.g., deposits). For instrument categories "short-term loans", "medium- and long-term loans" and "insurance, pension and guaranteed funds", the data does not provide a complete sectoral disaggregation on the asset side. Hence, the classification is based on liability-side information.

For the remaining sector-instruments, the principle of maximum entropy is applied, following previous literature (most closely Castrén and Kavonius, 2009, inspired by Allen and Gale, 2000). This is, asset positions of sector $\mathrm{i}$ on sector $\mathrm{j}$ are obtained multiplying the marginal distribution of sector $i$ assets times the marginal distribution of sector $j$ liabilities. Typically, these "unclassifiable" instruments are reported in the data as assets of sector $i$ in "other sectors", or liabilities of sector i with respect to "other sectors".

This classification approach ensures that all instruments are allocated to both a creditor and a debtor sector. Hence, the total sum of assets and liabilities in each instrument is consistent with the balance sheet positions of the whole economy in that instrument. 


\section{APPENDIX II. FinANCIAL EXPOSURES OVER TIME}

\begin{tabular}{|c|c|c|c|c|c|c|c|c|c|c|}
\hline \multirow[b]{2}{*}{ 1995:Q1 } & \multirow[b]{2}{*}{ NFC } & \multicolumn{7}{|c|}{$\begin{array}{l}\text { Sectoral Financial Asset Exposures over Time } \\
\text { (Percent of GDP) }\end{array}$} & \multirow[b]{2}{*}{ Tot. As. } & \multirow[b]{2}{*}{ NFA } \\
\hline & & MFI & BOI & OFI & INP & GOV & HH & RoW & & \\
\hline NFC & & 7 & 2 & 1 & 2 & 5 & 5 & 10 & 33 & -67 \\
\hline MFI & 39 & & 2 & 2 & 0 & 25 & 16 & 14 & 97 & -1 \\
\hline BOI & 0 & 2 & & 0 & 0 & 9 & 0 & 5 & 17 & 3 \\
\hline OFI & 7 & 3 & 0 & & 0 & 5 & 1 & 6 & 21 & $\mathbf{0}$ \\
\hline INP & 2 & 2 & 0 & 0 & & 4 & 0 & 2 & 9 & -5 \\
\hline GOV & 9 & 5 & 1 & 6 & 1 & & 1 & 2 & 24 & -77 \\
\hline HH & 33 & 54 & 8 & 11 & 10 & 35 & & 10 & 162 & 139 \\
\hline RoW & 11 & 24 & 1 & 1 & 1 & 18 & 0 & & 56 & 8 \\
\hline Tot. Liab. & 100 & 98 & 14 & 21 & 14 & 102 & 23 & 48 & 418 & \\
\hline 2001:Q4 & NFC & MFI & BOI & OFI & INP & GOV & HH & RoW & Tot. As. & NFA \\
\hline NFC & & 14 & 1 & 2 & 3 & 4 & 6 & 18 & 48 & -96 \\
\hline MFI & 46 & & 1 & 3 & 1 & 17 & 20 & 15 & 104 & -19 \\
\hline BOI & 0 & 1 & & 0 & 0 & 5 & 0 & 6 & 12 & 4 \\
\hline OFI & 11 & 7 & 0 & & 0 & 12 & 4 & 24 & 58 & 10 \\
\hline INP & 3 & 3 & 0 & 2 & & 9 & 0 & 8 & 25 & -7 \\
\hline GOV & 8 & 5 & 0 & 5 & 1 & & 3 & 3 & 26 & -92 \\
\hline HH & 52 & 63 & 5 & 31 & 23 & 34 & & 23 & 231 & 198 \\
\hline RoW & 24 & 31 & 0 & 4 & 2 & 37 & 0 & & 100 & 2 \\
\hline Tot. Liab. & 145 & 123 & 8 & 47 & 31 & 117 & 34 & 97 & 603 & \\
\hline 2008:Q1 & NFC & MFI & BOI & OFI & INP & GOV & HH & RoW & Tot. As. & NFA \\
\hline NFC & & 15 & 2 & 1 & 3 & 6 & 6 & 19 & 50 & -126 \\
\hline MFI & 61 & & 1 & 6 & 1 & 24 & 29 & 24 & 146 & -13 \\
\hline BOI & 0 & 1 & & 0 & 0 & 4 & 0 & 9 & 15 & 3 \\
\hline OFI & 12 & 6 & 0 & & 0 & 4 & 9 & 17 & 48 & 18 \\
\hline INP & 4 & 5 & 0 & 1 & & 8 & 0 & 15 & 34 & -3 \\
\hline GOV & 10 & 6 & 1 & 2 & 1 & & 4 & 2 & 24 & -89 \\
\hline HH & 58 & 80 & 6 & 13 & 30 & 24 & & 24 & 235 & 187 \\
\hline RoW & 32 & 47 & 1 & 7 & 2 & 43 & 0 & & 133 & 22 \\
\hline Tot. Liab. & 177 & 159 & 11 & 30 & 37 & 113 & 48 & 111 & 686 & \\
\hline
\end{tabular}




\begin{tabular}{|c|c|c|c|c|c|c|c|c|c|c|}
\hline \multirow[b]{2}{*}{ 2012:Q2 } & \multicolumn{10}{|c|}{$\begin{array}{c}\text { Sectoral Financial Asset Exposures over Time (concluded) } \\
\text { (Percent of GDP) }\end{array}$} \\
\hline & NFC & MFI & BOI & OFI & INP & GOV & HH & RoW & Tot. As. & NFA \\
\hline NFC & & 11 & 4 & 1 & 1 & 7 & 5 & 26 & 54 & -116 \\
\hline MFI & 66 & & 3 & 14 & 1 & 37 & 38 & 29 & 188 & -2 \\
\hline BOI & 0 & 18 & & 0 & 0 & 6 & 0 & 14 & 37 & 7 \\
\hline OFI & 12 & 21 & 1 & & 0 & 11 & 5 & 17 & 67 & 29 \\
\hline INP & 3 & 3 & 0 & 2 & & 13 & 0 & 14 & 36 & -2 \\
\hline GOV & 10 & 5 & 1 & 2 & 0 & & 4 & 4 & 27 & -103 \\
\hline HH & 47 & 76 & 14 & 10 & 34 & 18 & & 26 & 225 & 171 \\
\hline RoW & 31 & 57 & 8 & 9 & 2 & 38 & 1 & & 146 & 17 \\
\hline Tot. Liab. & 170 & 190 & 31 & 38 & 38 & 130 & 54 & 129 & 780 & \\
\hline 2017:Q3 & NFC & MFI & BOI & OFI & INP & GOV & HH & RoW & Tot. As. & NFA \\
\hline NFC & & 14 & 7 & 1 & 2 & 6 & 5 & 27 & 61 & -112 \\
\hline MFI & 54 & & 5 & 13 & 1 & 37 & 37 & 23 & 170 & $\mathbf{0}$ \\
\hline BOI & 0 & 16 & & 0 & 0 & 22 & 0 & 13 & 53 & 6 \\
\hline OFI & 11 & 18 & 2 & & 0 & 8 & 4 & 26 & 69 & 27 \\
\hline INP & 4 & 3 & 1 & 3 & & 20 & 0 & 25 & 55 & -2 \\
\hline GOV & 11 & 5 & 1 & 4 & 1 & & 4 & 4 & 30 & -124 \\
\hline HH & 54 & 64 & 19 & 16 & 50 & 14 & & 30 & 247 & 196 \\
\hline RoW & 39 & 50 & 12 & 6 & 3 & 47 & 1 & & 157 & 8 \\
\hline Tot. Liab. & 174 & 170 & 47 & 42 & 56 & 154 & 51 & 149 & 843 & \\
\hline
\end{tabular}




\section{APPENDIX III. ESTIMATION OF THE IMPACT OF SHOCKS}

\section{Valuation Shock}

Formally, the direct impact on sector i's NFA of a shock to the value of its instrument-k assets in sector $\mathrm{j}$ is given by

$$
d_{i j k}=\Delta p_{j k} a_{i j k}, \text { if } i \neq j
$$

and for sector $i=j$ :

$$
d_{j j k}=-\Delta p_{j k} l_{j k}
$$

where $\Delta p_{j k}$ is the change in value of instrument k issued by sector $\mathrm{j}, a_{i j k}$ the holdings of sector $\mathrm{i}$ in instrument-k liabilities of sector $\mathrm{j}$, and $l_{j k}$ the total instrument-k liabilities of sector j. The vector $\vec{d}_{j k}$ collects the impact for all sectors.

To calculate the indirect impact through equity linkages, sectors are divided into ultimate equity owners $\{\mathrm{BOI}, \mathrm{GOV}, \mathrm{HH}$ or RoW $\}$ and others. The four ultimate owner sectors together own all the equity issued by other sectors and have no equity liabilities themselves, so they end up absorbing all shocks.

The calculation involves two steps. First, the intermediate equity impact $e^{\prime}$ among the nonabsorber sectors is calculated as

$$
e^{\prime}{ }_{i j k}=(I-M)^{-1} \sum_{s=\{\mathrm{NFC}, \mathrm{MFI}, \mathrm{OFI}, \mathrm{INP}\}} d_{s j k} E^{\prime}{ }_{i s}, \text { if } i=\{\mathrm{NFC}, \mathrm{MFI}, \mathrm{OFI}, \mathrm{INP}\},
$$

where $I$ is the identity matrix,

$$
M \equiv E^{\prime}-\operatorname{diag}\left(E^{\prime}\right)-\lambda\left(E^{\prime}-\operatorname{diag}\left(E^{\prime}\right)\right) I,
$$

$\lambda$ is a vector of ones and $E^{\prime}$ is a matrix showing the fraction of sector s's equity owned by sector i if $i \neq s$ and equal to the residual share otherwise, defined for $i=$ $\{\mathrm{NFC}, \mathrm{MFI}, \mathrm{OFI}, \mathrm{INP}\}{ }^{9}$ The matrix $M$ captures the difference between a sector's equity holdings in other sectors (off-diagonal entries) and its equity liabilities (diagonal entries). The geometric-sum term $(I-M)^{-1}$ reflects the infinite rounds of knock-on effects across sectors interlinked by mutual equity exposures.

Second, the ultimate equity impact $e$ for the shock absorbers is calculated as

\footnotetext{
${ }^{9}$ Equity positions include both the ESA category "shares and other equity" and the fraction of non-moneymarket mutual fund positions which are invested in shares and other equity (15 percent).
} 


$$
e_{i j k}=\sum_{s=\{\mathrm{NFC}, \mathrm{MFI}, \mathrm{OFI}, \mathrm{INP}\}} e_{s j k}^{\prime} E_{i s}, \text { if } i=\{\mathrm{BOI}, \mathrm{GOV}, \mathrm{HH}, \mathrm{RoW}\},
$$

where $E$ is a matrix showing the fraction of sector s's equity owned by sector i, imposing zero ownership for $i=\{\mathrm{NFC}, \mathrm{MFI}, \mathrm{OFI}, \mathrm{INP}\} .{ }^{10}$

For the non-absorber sectors, the equity impact is simply the opposite of the direct impact:

$$
e_{i j k}=-d_{i j k}, \text { if } i=\{\mathrm{NFC}, \mathrm{MFI}, \mathrm{OFI}, \mathrm{NPI}\} \text {, }
$$

which makes the total impact zero. This is because any change in the value of their assets leads to a one-to-one change in the value of their equity liabilities with respect to other sectors.

The total NFA impact across sectors is the sum of the direct and indirect impact of the shock:

$$
\Delta N F A=\vec{d}_{j k}+\vec{e}_{j k}
$$

\section{Bail-in Scenario}

The direct impact is given by the sum of the valuation change in MFI equity and bond liabilities times the exposure of each sector to these two assets.

Since in a bail-in equity is wiped out, original shareholders do not benefit from the reduction in bond liabilities, so there is no indirect equity impact for MFIs:

$$
e_{i j k}=0 \text {, if } i=\mathrm{MFI} \text {. }
$$

For the rest of non-absorber sectors, the intermediate equity impact is:

$$
e_{i j k}^{\prime}=\left(I-M^{\prime \prime}\right)^{-1} \sum_{s=\{\mathrm{NFC}, \mathrm{OFI}, \mathrm{INP}\}} d_{s j k} E^{\prime \prime}{ }_{i s}, \text { if } i=\{\mathrm{NFC}, \mathrm{OFI}, \mathrm{INP}\}
$$

where $E^{\prime \prime}$ and $M^{\prime \prime}$ are respectively defined like $E^{\prime}$ and $M$ but only for sectors $i=$ $\{\mathrm{NFC}, \mathrm{OFI}, \mathrm{INP}\}$.

The ultimate equity impact for sectors other than MFIs is given by the same formulas as in the valuation shock case above.

\footnotetext{
${ }^{10}$ Given the lack of perfect sector-by-sector disaggregation in the data, non-absorption by $i=$ $\{\mathrm{NFC}, \mathrm{MFI}, \mathrm{OFI}, \mathrm{NPI}\}$ has to be imposed as a constraint in the calculation.
} 


\section{Bailout Scenario}

In a bailout, the government makes a transfer $\mathrm{t}$ to affected bank bondholders equal to the loss in value of their bonds:

$$
t=\Delta p_{j k} \sum_{i} a_{i j k}, \text { where } j=\text { MFI and } k=\text { bond }
$$

Hence, the direct impact for the government is equal to $-t$. For other sectors, the direct impact is given by their exposure to MFI equity.

The ultimate equity impact for MFIs is equal to the difference between the bail-in direct impact and the bailout direct impact (as the former does not include the government transfer, which is ultimately transmitted to MFI shareholders).

For the rest of non-absorber sectors:

$$
e_{i j k}^{\prime}=(I-M)^{-1} \sum_{s=\{\mathrm{NFC}, \mathrm{MFI}, \mathrm{OFI}, \mathrm{INP}\}} d_{s j k}^{\prime} E^{\prime}{ }_{i s}, \text { if } i=\{\mathrm{NFC}, \mathrm{OFI}, \mathrm{INP}\} \text {, }
$$

Where $d_{s j k}^{\prime}$ is equal to $d_{s j k}$ if $s=\{\mathrm{NFC}, \mathrm{OFI}, \mathrm{INP}\}$, and equal to minus the ultimate equity impact for MFIs if $s=$ MFI.

The ultimate equity impact for sectors other than MFIs is given by the same formulas as in the valuation shock case. 


\section{APPENDix IV. BANK SHOCK COUnTERFACTUAL Simulations}

This appendix shows the total NFA change after a bail-in and a bailout under alternative assumptions for the bond conversion rate (Table A1). The baseline shows the impact assuming that 50 percent of the value of bonds is recovered after bonds are converted to equity, while the alternative shows the impact under a zero conversion rate.

A lower conversion rate increases total bondholder losses, and thus the required government transfer in a bailout. In the bail-in case, the additional impact is roughly proportionally distributed across sectors.

\begin{tabular}{|l|rrrr|}
\hline \multicolumn{3}{|c|}{ Table A1. Impact of Bank Shocks, No Bond Conversion Counterfactual } \\
& \multicolumn{2}{|c|}{$\begin{array}{l}\text { (Percent of GDP) } \\
\text { bail in }\end{array}$} & \multicolumn{2}{c|}{ bail out } \\
& baseline & no convers. & baseline & no convers. \\
\hline NFC & 0.0 & 0.0 & 0.0 & 0.0 \\
MFI & 2.3 & 3.2 & 2.3 & 3.2 \\
BOI & -0.1 & -0.2 & 0.0 & 0.0 \\
OFI & 0.0 & 0.0 & 0.0 & 0.0 \\
INP & 0.0 & 0.0 & 0.0 & 0.0 \\
GOV & -0.1 & -0.1 & -1.6 & -3.2 \\
HH & -1.2 & -1.6 & -0.4 & 0.0 \\
RoW & -0.9 & -1.3 & -0.2 & 0.0 \\
\hline Source: Bank of Italy (via Haver) and staff calculations. & & & \\
\hline
\end{tabular}

